\title{
An Updated Review of the Invasive Aedes albopictus in the Americas; Geographical Distribution, Host Feeding Patterns, Arbovirus Infection, and the Potential for Vertical Transmission of Dengue Virus
}

\author{
Julian E. Garcia-Rejon ${ }^{1}$ (D), Juan-Carlos Navarro ${ }^{2, *(D)}$, Nohemi Cigarroa-Toledo ${ }^{3}$ and Carlos M. Baak-Baak ${ }^{1, *(D)}$ \\ 1 Centro de Investigaciones Regionales, Laboratorio de Arbovirologia, Universidad Autonoma de Yucatan, \\ Merida 97069, Yucatan, Mexico; julian.garcia@correo.uady.mx \\ 2 Grupo de Investigación en Enfermedades Emergentes, Desatendidas, Ecopidemiología y Biodiversidad, \\ Facultad de Ciencias de la Salud, Universidad Internacional SEK, Quito 170107, Ecuador \\ 3 Centro de Investigaciones Regionales, Laboratorio de Biología Celular, Universidad Autonoma de Yucatan, \\ Merida 97069, Yucatan, Mexico; nohemi.cigarroa@correo.uady.mx \\ * Correspondence: juancarlos.navarro@uisek.edu.ec (J.-C.N.); carlos.baak@correo.uady.mx (C.M.B.-B.)
}

\section{check for} updates

Citation: Garcia-Rejon, J.E.; Navarro, J.-C.; Cigarroa-Toledo, N.; Baak-Baak, C.M. An Updated Review of the Invasive Aedes albopictus in the Americas; Geographical Distribution, Host Feeding Patterns, Arbovirus Infection, and the Potential for Vertical Transmission of Dengue Virus. Insects 2021, 12, 967. https:/ / doi.org/10.3390/insects12110967

Academic Editor: Ann Fallon

Received: 4 September 2021 Accepted: 8 October 2021

Published: 26 October 2021

Publisher's Note: MDPI stays neutral with regard to jurisdictional claims in published maps and institutional affiliations.

Copyright: (c) 2021 by the authors. Licensee MDPI, Basel, Switzerland. This article is an open access article distributed under the terms and conditions of the Creative Commons Attribution (CC BY) license (https:/ / creativecommons.org/licenses/by/ $4.0 /)$.
Simple Summary: Currently, the Asian tiger mosquito Aedes albopictus Skuse is present on all continents except Antarctica. Efficiency as a vector of Ae. albopictus is different by geographic region. In areas where Aedes aegypti is absent, the Asian mosquito is the main vector of arboviruses such as dengue, Zika, and chikungunya. In the Americas, Ae. albopictus occupies the same ecological niches as Ae. aegypti. It is difficult to incriminate the Asian mosquito as the cause of autochthonous arbovirus outbreaks. However, evidence suggests that Ae. albopictus is very effective in transmitting endemic arboviruses (such as dengue) both horizontal and vertical transmission. Aedes albopictus could be useful as a sentinel species to monitor dengue virus in interepidemic periods.

Abstract: Aedes (Stegomyia) albopictus is a mosquito native to Southeast Asia. Currently, it has a wide distribution in America, where natural infection with arboviruses of medical and veterinary importance has been reported. In spite of their importance in the transmission of endemic arbovirus, the basic information of parameters affecting their vectorial capacity is poorly investigated. The aim of the work was to update the distribution range of Ae. albopictus in the Americas, review the blood-feeding patterns, and compare the minimum infection rate (MIR) of the Dengue virus (DENV) between studies of vertical and horizontal transmission. The current distribution of $A e$. albopictus encompasses 21 countries in the Americas. An extensive review has been conducted for the blood-feeding patterns of Ae. albopictus. The results suggest that the mosquito is capable of feeding on 16 species of mammals and five species of avian. Humans, dogs, and rats are the most common hosts. Eight arboviruses with the potential to infect humans and animals have been isolated in $A e$. albopictus. In the United States of America (USA), Eastern equine encephalitis virus, Keystone virus, La Crosse Virus, West Nile virus, and Cache Valley virus were isolated in the Asian mosquito. In Brazil, Mexico, Colombia, and Costa Rica, DENV (all serotypes) has been frequently identified in field-caught Ae. albopictus. Overall, the estimated MIR in Ae. albopictus infected with DENV is similar between horizontal (10.95) and vertical transmission (8.28). However, in vertical transmission, there is a difference in the MIR values if the DENV is identified from larvae or adults (males and females emerged from a collection of eggs or larvae). MIR estimated from larvae is 14.04 and MIR estimated in adults is 4.04 . In conclusion, it has to be highlighted that Ae. albopictus is an invasive mosquito with wide phenotypic plasticity to adapt to broad and new areas, it is highly efficient to transmit the DENV horizontally and vertically, it can participate in the inter-endemic transmission of the dengue disease, and it can spread zoonotic arboviruses across forest and urban settings. 
Keywords: Asian tiger mosquito; feeding pattern; minimum infection rate; emerging arboviruses; Dengue virus

\section{Introduction}

Aedes (Stegomyia) albopictus Skuse is a mosquito native to Southeast Asia, colloquially known as the Asian tiger mosquito or Asian mosquito. The mosquito was described by Skuse (1894) in the city of Calcutta, India [1,2]. At the beginning of 2000's, its importance as a vector of arboviruses was restricted to Asian and African countries [1]. Currently, Ae. albopictus is present on all continents except Antarctica [3]. It has been observed that once established in new geographic areas, it can become involved in the natural cycles of arbovirus transmission. For example, in Europe it has colonized several countries and was involved in dengue outbreaks in France, Italy, and Spain [4-6]. In Italy, the genome of the chikungunya virus was identified in Ae. albopictus and it was incriminated as the vector that caused the local outbreaks of chikungunya fever [7]. Likewise, autochthonous cases of Zika fever occurred in France and Ae. albopictus was suspected as the transmitter of the virus [8]. In America, dengue virus is the most important mosquito-borne viruses in terms of its global impact on human morbidity and mortality. Approximately 23 million dengue cases were registered across the Americas between 1980 and 2017. In 2019 there was a resurgence of the dengue virus, reaching 3.1 million cases throughout the region [9]. chikungunya and Zika viruses are emerging viruses in America that have caused explosive outbreaks from 2013 to 2016, which has since subsided [10]. Aedes aegypti is the main vector of dengue, Zika, and chikungunya viruses in the region [10-14]. The antecedents demonstrate that $A e$. albopictus can transmit these viruses $[5,7,11,14]$; therefore, it is considered a species with the potential to increase the risk of arbovirus transmission in America.

Aedes albopictus has a wide distribution in America [3,15-35]. The USA [1] began the surveillance of the geographic distribution throughout America since 1985, when it became known that the Asian mosquito had colonized the state of Texas, and studies were carried out on the pattern of blood-feeding and the transmission of arboviruses. Studies on the blood-feeding pattern of Ae. albopictus have been carried out in the United States of America and Brazil [36-46]. The results show that it is an opportunistic mosquito. DNA from humans and a diverse range of wild and domestic animals have been identified in the blood meal of the mosquito [38,39,41,45].

In America, arboviruses of medical and veterinary importance have been isolated in field-caught Ae. albopictus [47-68]. Notably, the Asian mosquito has a great capacity to acquire arboviruses and transmit them to its offspring. The findings of transovarian transmission have been consistent and very frequent [56-58]. Studies carried out in North and South America have found the dengue (all serotypes), Zika and La Crosse viruses in larvae and males of Ae. albopictus [57,60,62-64]. Evidences suggest that the mosquito may have a reservoir role for the dengue virus by keeping it silent in nature [56]. In Brazil, the detection of DENV-3 in males of Ae. albopictus was carried out in years in which no autochthonous human cases with this serotype were recorded, suggesting that the silent circulation of DENV-3 occurs by a vertical transmission mechanism [68]. Additionally, yellow fever virus was isolated in Ae. albopictus females in Rio de Janeiro State, which could imply that it could be acting as an additional jungle or rural vector causing a possible transmission bridge to the urban area [47].

At this point, the distribution range of Ae. albopictus in the Americas was updated, the blood feeding patterns were reviewed, and the minimum infection rate of the dengue virus between studies of vertical and horizontal transmission was compared. 


\section{Selection Criteria and Search Strategy}

The analysis only included works carried out in the Americas (North, South, Central, and the Caribbean), with topics focused on the first report of Ae. albopictus from each American country, blood feeding patterns, and reports of natural infection with arbovirus.

Databases of Google Scholar, PubMed Health (National Center for Biotechnology Information at the National Library of Medicine), SciELO (Scientific Electronic Library Online), and Web of Science (Thompson Reuters) were used for the literature review. The search was done with combination of keywords including "Aedes albopictus" AND "first report", "first record", "new records", "blood meal", "feeding pattern", “arbovirus" "Dengue", "Zika", "chikungunya", "America". Additional references were facilitated by colleagues.

Importation of references and removal of duplicate references were done by using the bibliographical software package, Mendeley version 1.19.8 (Elsevier, Amsterdam, Netherlands). All titles, abstracts and selected full reports were screened independently by two authors based on the inclusion and exclusion criteria. Discrepancies were resolved by consensus.

\section{Statistical Analysis}

Test for the difference of proportions was used to compare the positive pools between studies with vertical and horizontal transmission cycle. The MIR values of each study were extracted manually and were organized in an Excel sheet. When the work did not include the MIR, it was calculated with the following formula:

$$
\mathrm{MIR}=\frac{\text { Number of positive pools }}{\text { Total numbers of mosquitoes tested }} \times 1000
$$

Host frequencies identified in blood meals of Ae. albopictus were extracted from each work and were organized in an Excel sheet. Statistical analyses were performed by using $R$ statistical programming language version 4.0.2, and results were considered statistically significant when $p \leq 0.05$.

\section{Chronological Order of the First Reports of Ae. albopictus in the Americas}

The current distribution of Ae. albopictus encompasses 21 of 44 countries in the Americas, although the colonization pattern is different in each country (Table 1) and Chile and Peru have not reported any data yet. Previously, Kramer and collaborators [3] conducted a global compendium of the distribution of Ae. albopictus and described its presence in 16 countries of the Americas. According to reports, the mosquito has presented an erratic distribution, but with great rapidity in its movement through America. The introduction of Ae. albopictus in America was divided into four periods. In the first period (1983-1990), the Asian mosquito was reported in three countries. The first report occurred in the USA in 1983, when a single adult of Ae. albopictus was captured in a cemetery in Memphis, Tennessee [15]. Three years later, five male and six female mosquitoes with similar characteristics to the Asian mosquito were captured and their identity was confirmed as Ae. albopictus in Brazil (1986) [16]. In Mexico, the Asian mosquito was reported for the first time in 1988: the larvae were collected in tires [17]. In the second period (1993-1998), the Asian mosquito was reported in six countries including the Dominican Republic, Cuba, Guatemala, the Cayman Islands, Colombia, and Argentina [18-23]. Reiter [15] mentions that Ae. albopictus was reported in Bolivia and El Salvador, but there are no reports that confirm this. Their presence in these countries is not currently recognized. In the third period (2000-2010), the mosquito significantly expanded its distribution to ten countries, including Bermuda, Canada, Trinidad and Tobago, Panama, Uruguay, Nicaragua, Costa Rica, Venezuela, Belize, and Haiti [24-33]. In the fourth period (2011-2021), the presence of the mosquito was only reported in Ecuador in 2017 and in Jamaica in 2018 [34,35]. It is well documented that the introduction of Ae. albopictus into America occurred through tires and bamboo stumps imported from Japan. It is also hypothesized that the massive 
distribution of the mosquito occurred through the export of used tires among countries in the Americas, Europe and Asia [1,15-17]. Within countries, automobiles are believed to contribute to the distribution [69].

Table 1. Chronological summary of publications on the first reports of Ae. albopictus in American countries.

\begin{tabular}{|c|c|c|c|}
\hline $\begin{array}{l}\text { Year of the First } \\
\text { Report }\end{array}$ & Country & Collected Stage of the Mosquito & Author \\
\hline 1983 & USA & A single adult collected & [15] \\
\hline 1986 & Brazil & Captured five males and six females & [16] \\
\hline 1988 & Mexico & Larvae collected in tires & [17] \\
\hline 1995 & Cuba & Larvae collected & [18] \\
\hline 1993 & Dominican Republic & Larvae collected in tires & [19] \\
\hline 1995 & Guatemala & $\begin{array}{l}\text { Larvae collected in tires, glass bottles, } \\
\text { and metal drums. }\end{array}$ & [20] \\
\hline 1997 & Cayman island & Larvae collected & [21] \\
\hline 1998 & Colombia & Captured adults & [22] \\
\hline 1998 & Argentina & Larvae and pupae collected & [23] \\
\hline 2000 & Bermuda Island & Larvae collected & {$[24]$} \\
\hline 2002 & Panama & Larvae collected & [25] \\
\hline 2001 & Canada & Two adults captured & [26] \\
\hline 2002 & Trinidad and Tobago & Eggs collected with ovitrap & [27] \\
\hline 2003 & Uruguay & Adults captured & [28] \\
\hline 2003 & Nicaragua & Larvae collected & [29] \\
\hline 2007 & Costa Rica & Larvae collected & {$[30]$} \\
\hline 2009 & Venezuela & Larvae collected & {$[31]$} \\
\hline 2009 & Belize & Adults captured & [32] \\
\hline 2010 & Haiti & Larvae collected & {$[33]$} \\
\hline 2017 & Ecuador & Captured 5 males and 16 females & [34] \\
\hline 2018 & Jamaica & Six females captured & [35] \\
\hline
\end{tabular}

\section{Blood Feeding Pattern of Ae. albopictus}

There are a total of 11 published papers on the blood feeding pattern of Ae. albopictus; nine of them were carried out in the USA and two in Brazil. The first four studies used the serological precipitin test and ELISAs to identify the identity of the vertebrate hosts [36-39]. Seven publications used PCR to identify host DNA [40-46]. Moreover, 1925 individual mosquitos were tested in total. In $85.56 \%(1647 / 1925)$ of the mosquitos, the host was identified at the species level, which comprised 16 species of mammals and five species of avian (Table 2). Despite the ability of Ae. albopictus to feed on the blood of different vertebrate taxa, $98.70 \%(1900 / 1925)$ corresponded to mammals. The human (Homo sapiens), the domestic dog (Canis lupus), the brown rat (Rattus norvegicus), and the domestic cat (Felis silvestris) are the most frequent hosts in the publications and with more specimens analyzed (Table 2). 
Table 2. DNA of vertebrate hosts identified in blood meals of Aedes albopictus.

\begin{tabular}{|c|c|c|c|}
\hline Family & Vertebrate Host & Total Identified & Author \\
\hline \multicolumn{4}{|c|}{ Mammalian } \\
\hline Hominidae & Homo sapiens & 579 & {$[36-39,41-46]$} \\
\hline Muridae & Rattus norvegicus & 227 & {$[37-39,44-46]$} \\
\hline Felidae & Felis silvestris & 252 & {$[38,39,41,43,44]$} \\
\hline Canidae & Canis lupus & 217 & {$[36,38-41,43-46]$} \\
\hline Sciuridae & Sciurus carolinensis & 110 & {$[41,43]$} \\
\hline Leporidae & Sylvilagus floridanus & 95 & {$[37,38,43]$} \\
\hline Cervidae & Odocoileus virginianus & 52 & {$[36,38,41,44]$} \\
\hline Equidae & Equus caballus & 49 & [39-41] \\
\hline Bovidae & Bos taurus & 29 & {$[36,38,39]$} \\
\hline Didelphidae & Didelphis virginiana & 8 & {$[42,43]$} \\
\hline Sciuridae & Tamias striatus & 7 & [38] \\
\hline Suidae & Sus scrofa & 5 & {$[39,46]$} \\
\hline Emydidae & Terrapene carolina & 5 & [38] \\
\hline Phyllostomidae & Tonatia bidens & 2 & [45] \\
\hline Cricetidae & Peromyscus leucopus & 1 & [43] \\
\hline Dasypodidae & Dasypus novemcintus & 1 & [37] \\
\hline \multicolumn{4}{|c|}{ Avian } \\
\hline Phasianidae & Gallus domesticus & 4 & [39] \\
\hline Cardinalidae & Cardinalis cardinalis & 1 & [42] \\
\hline Paridae & Poecile carolinensis & 1 & [42] \\
\hline Columbidae & Zenaida macroura & 1 & [42] \\
\hline Tamnophilide & Taraba major & 1 & [45] \\
\hline Grand total & & 1647 & \\
\hline
\end{tabular}

Unidentified mammals: Leporidae $(n=119)$; Didelphidae $(n=68)$; Procyonidae $(n=58)$; Sciuridae $(n=8)$ Murid $(n=4)$; ); Myomorpha $(n=4)=261$. Unidentified birds: Passeriformes $(n=10)$; Columbiformes $(n=5)$; Ciconiiformes $(n=1)$ Quail $(n=1)=17$.

The frequency of blood feeding of Ae. albopictus on a particular host determines the risk of pathogen transmission. According to studies mainly published in the USA, the Asian mosquito has an anthropophilic tendency, although in the absence of humans it can feed on 15 other species of mammals and five species of avian. The method and the place of capture of Ae. albopictus was decisive to identify DNA of hosts in the blood meals of the mosquito. Most females of Ae. albopictus with human blood were captured with the human bait method and aspirated from mosquitoes indoors and outdoors [37,39,41,43]. The other works captured Ae. albopictus in the forest or habitats with abundant vegetation. For this reason, the number of wild species in the blood meals of the Asian mosquito was very diverse $[36,38,40,42,44-46]$. In the USA, the feeding frequency of Ae. albopictus on avian and wild mammals partly explains the isolation of zoonotic arboviruses (Table 3) [48-51,62]. 
Table 3. Chronological summary of publications on natural infection of Ae. albopictus with arboviruses of medical and veterinary importance.

\begin{tabular}{|c|c|c|c|c|c|}
\hline Year & Country & Arbovirus & $\begin{array}{l}\text { Detection } \\
\text { Technique }\end{array}$ & Author & Observations \\
\hline 1991 & USA & EEEV & $\begin{array}{c}\text { IFAA, Viral } \\
\text { isolation, PRNT }\end{array}$ & {$[48]^{\mathrm{H}}$} & $\begin{array}{l}\text { EEEV was isolated from } 14 \text { pools of } \\
\text { females }\end{array}$ \\
\hline 1991 & USA & Keystone virus & $\begin{array}{l}\text { IFAA, Viral } \\
\text { isolation, PRNT }\end{array}$ & {$[48]^{\mathrm{H}}$} & $\begin{array}{l}\text { Keystone virus was isolated from a pool } \\
\text { of females }\end{array}$ \\
\hline 1993 & Brazil & DENV-1 & $\begin{array}{l}\text { Viral isolation, } \\
\text { PCR }\end{array}$ & {$[58]^{\mathrm{V}}$} & $\begin{array}{l}\text { DENV-1 was isolated from two pools of } \\
\qquad 30 \text { larvae. }\end{array}$ \\
\hline 1995 & USA & $\mathrm{CVV}$ & $\begin{array}{l}\text { Viral isolation, } \\
\text { IFAA }\end{array}$ & {$[49]^{\mathrm{H}}$} & $\begin{array}{l}\text { CVV was isolated from a pool of } \sim 100 \\
\text { females }\end{array}$ \\
\hline 1995 & Mexico & $\begin{array}{l}\text { DENV-2 and } \\
\text { DENV-3. }\end{array}$ & $\begin{array}{l}\text { Viral isolation, } \\
\text { IFAA, RT-PCR }\end{array}$ & {$[61]^{\mathrm{V}}$} & $\begin{array}{l}\text { DENV-2 and DENV-3 were isolated from } \\
\text { a pool of ten males }\end{array}$ \\
\hline 1999 & USA & La Crosse Virus & $\begin{array}{l}\text { Viral isolation, } \\
\text { RT-PCR }\end{array}$ & {$[62]^{\mathrm{V}}$} & $\begin{array}{c}\text { Larvae reared to adults. La Crosse virus } \\
\text { was isolated from two pools of } 58 \\
\text { females. }\end{array}$ \\
\hline 1999 & Brazil & DENV-3 & PCR & {$[63]^{\mathrm{V}}$} & $\begin{array}{l}\text { DENV-3 was isolated from three pools of } \\
30 \text { larvae. }\end{array}$ \\
\hline 2000 & USA & WNV & RT-PCR & {$[50]^{\mathrm{H}}$} & $\begin{array}{l}\text { WNV was isolated from a pool of two } \\
\text { females }\end{array}$ \\
\hline 2002 & Colombia & $\begin{array}{l}\text { DENV-1 and } \\
\text { DENV-2 }\end{array}$ & RT-PCR & {$[11]^{\mathrm{H}}$} & $\begin{array}{l}\text { Two pools of } 26 \text { females were positive for } \\
\text { DENV-1, and DENV-2, respectively. }\end{array}$ \\
\hline 2003 & Brazil & DENV-2 & RT-PCR & {$[64]^{\mathrm{V}}$} & $\begin{array}{l}\text { DENV-2 was identified from } 33 \text { pools of } \\
1650 \text { larvae. Two Pools of } 100 \text { larvae were } \\
\text { coinfected with DENV-1 and DENV-2. }\end{array}$ \\
\hline 2003-2005 & USA & WNV & $\begin{array}{l}\text { Viral isolation, } \\
\text { ELISA }\end{array}$ & {$[46]^{\mathrm{H}}$} & WNV was isolated of females \\
\hline 2010 & USA & $\mathrm{CVV}$ & $\begin{array}{l}\text { Viral isolation, } \\
\text { RT-PCR }\end{array}$ & {$[51]^{\mathrm{H}}$} & $\begin{array}{l}\text { CVV was isolated from three pools of } A e . \\
\text { albopictus }\end{array}$ \\
\hline 2011 & Brazil & $\begin{array}{l}\text { DENV-2 and } \\
\text { DENV-3 }\end{array}$ & RT-PCR & {$[65]^{\mathrm{V}}$} & $\begin{array}{l}\text { DENV-2 was found in three individual } \\
\text { larvae. DENV-2 was found in a pool of } \\
\text { six larvae.An individual larva coinfected } \\
\text { with DENV-2 and DENV-3. }\end{array}$ \\
\hline 2007 & Brazil & $\begin{array}{l}\text { DENV-2 and } \\
\text { DENV-3 }\end{array}$ & $\begin{array}{l}\text { Viral isolation, } \\
\text { IFAA, RT-PCR }\end{array}$ & {$[66]^{\mathrm{V}}$} & $\begin{array}{l}\text { Larvae reared to adults. DENV-3 was } \\
\text { isolated from a pool of } 35 \text { adults. One } \\
\text { pool of } 41 \text { adults coinfected with DENV-2 } \\
\text { and DENV-3 }\end{array}$ \\
\hline 2010 & Mexico & $\begin{array}{l}\text { Dengue, serotype } \\
\text { unknown }\end{array}$ & RT-PCR & {$[67]^{\mathrm{V}}$} & $\begin{array}{l}\text { Larvae reared to adults. DENV was } \\
\text { found from a pool of four females. }\end{array}$ \\
\hline 2014-2015 & Brazil & DENV-3 & RT-PCR & {$[68]^{\mathrm{V}}$} & $\begin{array}{l}\text { Two pools of } 20 \text { males were positive for } \\
\text { DENV-3 }\end{array}$ \\
\hline 2015 & Costa Rica & $\begin{array}{l}\text { DENV-1, DENV-2, } \\
\text { DENV-4 }\end{array}$ & RT-PCR & {$[55]^{\mathrm{H}}$} & $\begin{array}{l}\text { Three pools of } 60 \text { females were positive } \\
\text { for DENV-1, DENV-2, and DENV-4, } \\
\text { respectively. }\end{array}$ \\
\hline 2015 & Costa Rica & $\begin{array}{l}\text { Dengue, serotype } \\
\text { unknown }\end{array}$ & RT-PCR & {$[55]^{\mathrm{V}}$} & $\begin{array}{c}\text { One pool of } 20 \text { males were positive for } \\
\text { DENV }\end{array}$ \\
\hline 2015 & Brazil & ZIKV & RT-qPCR & {$[59]^{\mathrm{V}}$} & $\begin{array}{c}\text { One pool of } 33 \text { larvae were positive for } \\
\text { ZIKV }\end{array}$ \\
\hline 2016 & Colombia & DENV-2 & RT-PCR & {$[52]^{\mathrm{H}}$} & $\begin{array}{l}\text { One pool of four females were positive } \\
\text { for DENV-2 }\end{array}$ \\
\hline
\end{tabular}


Table 3. Cont.

\begin{tabular}{|c|c|c|c|c|c|}
\hline Year & Country & Arbovirus & $\begin{array}{l}\text { Detection } \\
\text { Technique }\end{array}$ & Author & Observations \\
\hline 2016 & Mexico & ZIKV & RT-qPCR & {$[14]^{\mathrm{H}}$} & $\begin{array}{l}\text { One pool of six females were positive for } \\
\text { ZIKV }\end{array}$ \\
\hline 2016 & Colombia & DENV-2 & RT-PCR & {$[60]^{\mathrm{H}}$} & $\begin{array}{l}\text { Twenty pools of females were positive for } \\
\text { DENV-2 }\end{array}$ \\
\hline 2017 & Colombia & DENV-4 & RT-PCR & {$[60]^{\mathrm{V}}$} & $\begin{array}{l}\text { Five pools of } 31 \text { males were positive for } \\
\text { DENV-4 }\end{array}$ \\
\hline 2017 & Mexico & ZIKV & RT-qPCR & {$[53]^{\mathrm{H}}$} & $\begin{array}{l}\text { Seven pools of } 78 \text { females were positive } \\
\text { for ZIKV }\end{array}$ \\
\hline 2017 & Brazil & DENV-4 and ZIKV & $\begin{array}{l}\text { Viral isolation, and } \\
\text { RT-PCR }\end{array}$ & {$[57]^{\mathrm{V}}$} & $\begin{array}{l}\text { Eggs were reared until adulthood. Two } \\
\text { pools were positive for DENV-4 and two } \\
\text { pools were positive for ZIKV. }\end{array}$ \\
\hline 2018-2019 & Brazil & ZIKV and YFV & RT-PCR & {$[47]^{\mathrm{V}}$} & $\begin{array}{l}\text { Eggs were reared until adulthood. One } \\
\text { pool of nine females were positive for } \\
\text { YFV. One pool of } 32 \text { females and another } \\
\text { pool of two males were positive for ZIKV. }\end{array}$ \\
\hline 2019 & Brazil & DENV-1 and ZIKV & RT-qPCR & {$[54]^{\mathrm{H}}$} & $\begin{array}{l}\text { One pool of } 10 \text { females and another pool } \\
\text { of } 15 \text { females were positive for ZIKV and } \\
\text { DENV-1, respectively. }\end{array}$ \\
\hline
\end{tabular}

Indirect fluorescent antibody assay (IFAA); Polymerase Chain Reaction (PCR); Quantitative reverse transcription PCR (RT-qPCR); Plaquereduction neutralization Test (PRNT); Eastern equine encephalitis virus (EEEV); Cache Valley virus (CVV); West Nile virus (WNV); Yellow fever virus (YFV); Publications with super index ${ }^{\mathrm{H}}$ and ${ }^{\mathrm{V}}$ indicates horizontal and vertical transmission, respectively.

\section{Natural Infections of Ae. albopictus with Arboviruses}

In the Americas, there are 24 published papers on the identification of arboviruses in field-caught Ae. albopictus with the potential to infect humans and animals [11,14,47-68]. Ten of the findings were obtained in Brazil, six in the USA, four in Mexico, three in Colombia, and one in Costa Rica (Table 3). Eastern equine encephalitis virus, Keystone virus, Cache Valley virus, La Crosse virus, West Nile virus, dengue virus (all serotypes), yellow fever virus, and Zika virus were the arboviruses identified (Table 3).

Notably, $66.66 \%(16 / 24)$ of the publications reported the genome of the dengue virus in the Asian mosquito, although the presence was confirmed in only four studies via viral isolation $[57,58,61,66]$. In decreasing order, the most frequent serotypes in the publications are DENV-2 $(n=8)$, DENV-3 $(n=5)$, DENV-1 $(n=4)$, and DENV-4 $(n=3)$. On the other hand, the Zika virus was identified in Ae. albopictus in six studies carried out in Brazil $(n=4)$ and Mexico $(n=2)[14,47,53,54,57,59]$.

Aedes albopictus has a wide distribution in America. Despite this fact, the natural infection of Ae. albopictus with arboviruses of medical and veterinary importance has been reported only in five countries. Currently, eight arboviruses have been isolated in field-caught Ae. albopictus (Table 3). The Asian mosquito is a competent experimental vector of 16 arboviruses that circulate in America. Among the arboviruses experimentally transmitted by Ae. albopictus, there are viruses of the families Flaviviridae (dengue virus, Zika virus, West Nile virus, and yellow fever virus), Togaviridae (chikungunya virus, Eastern equine encephalitis virus, Mayaro virus, Ross River virus, Sindbis virus, Western equine encephalitis virus, and Venezuelan equine encephalitis virus), and Peribunyaviridae (Jamestown Canyon virus, Keystone virus, La Crosse virus, Potosi virus, and Rift Valley virus) [70-72].

In 2013, the chikungunya virus (CHIKV) emerged in the Americas and caused local outbreaks of chikungunya fever. To date, no natural infection with this virus has been reported in Ae. albopictus [12,13]. The Asian mosquito is an efficient vector of the epidemic mutant strain CHIKV_0621 of the East-Central-South African (ECSA) genotype [73], which, 
caused autochthonous cases of CHIKV in Indian Ocean [74]. Today, the circulation of the mutant strain in America is not reported.

The first findings of dengue virus in the Asian mosquito were obtained through vertical transmission. In Brazil, DENV-1 was isolated from two pools of mosquito larvae in 1993 [58]. Two years later, during a dengue outbreak in Mexico, DENV-2 and DENV-3 were isolated from a pool of 10 males of Ae. albopictus [61]. Again, in Brazil DENV-3 was identified in three larval pools in 1999 [63].

The Eastern equine encephalitis and Keystone were the first arboviruses isolated from the Asian mosquito, which were captured in a tire dump in Florida [48]. This was the first evidence of Ae. albopictus as a potential arbovirus vector in the region. In the USA, Eastern equine encephalitis virus, Keystone virus, La Crosse Virus, West Nile virus, and Cache Valley virus were isolated in field-caught Ae. albopictus [10-12,14,15,27]. Most of these viruses were identified by horizontal transmission, except for the La Crosse virus (LCV), which was isolated in two pools of females emerged from larvae collected in homes of patients with confirmed LAV encephalitis.

More than $70 \%$ of the publications of Ae. albopictus naturally infected with the dengue and Zika viruses come from Brazil, Mexico, Colombia, and Costa Rica, which are dengueendemic countries and between 2014 and 2018 there was active transmission of the Zika virus [10,11,14,47,52-55,57-61,63-68]. Notably, in 9 out of 10 studies carried out in Brazil, dengue (all serotypes), Zika, and yellow fever viruses were transmitted through a transovarial route $[47,57-59,63-66,68]$. Future studies should focus on finding out if there is an evolutionary relationship of arbovirus adaptation with vertical transmission of Ae. albopictus.

\section{The Minimum Infection Rate of the Dengue virus}

Some authors have pointed out that the MIR underestimates viral infection since it assumes that a positive pool corresponds to a single infected mosquito [60]. To correct the bias, some researchers pool a small number of mosquitoes $(\leq 10)$. Despite the bias, it is a parameter that is still used to find the probability of infected mosquitoes [55,60]. It is used as a measure to determine the capacity of Ae. albopictus as an efficient vector of arbovirus whose studies reported 12 vertical and 10 horizontal transmissions (Table 3]. Two studies carried out in Costa Rica and Colombia reported both types of transmission [55,60]. In 14 publications on vertical transmission [47,55,57-68], 19,435 mosquitoes organized in 792 pools were tested. Overall, $8.45 \%(67 / 792)$ of the pools were positive. The overall MIR was 3.45 per 1000 mosquitoes tested.

In contrast, in 12 publications on horizontal transmission [11,14,46,48-55,60], 53,566 mosquitoes organized in 5,956 pools were tested. Overall, $0.97 \%(58 / 5,956)$ of the pools were positive. The overall MIR was 1.08 per 1000 mosquitoes tested. The higher percentage of positive pools in vertical transmission contributed to a statistically significant difference compared to horizontal transmission $\left(X^{2}=215.46\right.$, d.f $\left.=1, p \leq 0.001\right)$.

When only DENV in vertical transmission was analyzed (Figure $1 \mathrm{~A}, \mathrm{~B}), 57$ positive pools of 6,883 mosquitoes were found $[55,57,58,60,61,63-68]$. Meanwhile, in horizontal transmission, 17 positive pools of 1,552 mosquitoes were found $[11,52,54,55,60]$. Therefore, MIR was slightly high in horizontal transmission (10.95) compared to vertical transmission (8.28) (Figure 1C,D). The estimated MIR in females of Ae. albopictus infected with DENV is in the range of 5.95 to $43.85[11,52,54,55,60]$. These values are similar to those estimated for Ae. aegypti $[11,60]$. This fact suggests that the Asian mosquito is also potentially effective in transmitting the DENV. The difference in the effectiveness to transmit the DENV is probably due to the endophilic and anthropophilic behavior of both mosquitoes. Aedes aegypti feeds almost exclusively on humans and rest inside the homes, taking more than one blood meal in each gonotrophic cycle [75-77]. While Ae. albopictus, although it feeds on humans, it is more opportunistic in its diet and prefers forest environments or areas with a lot of vegetation [36-39]. 
A
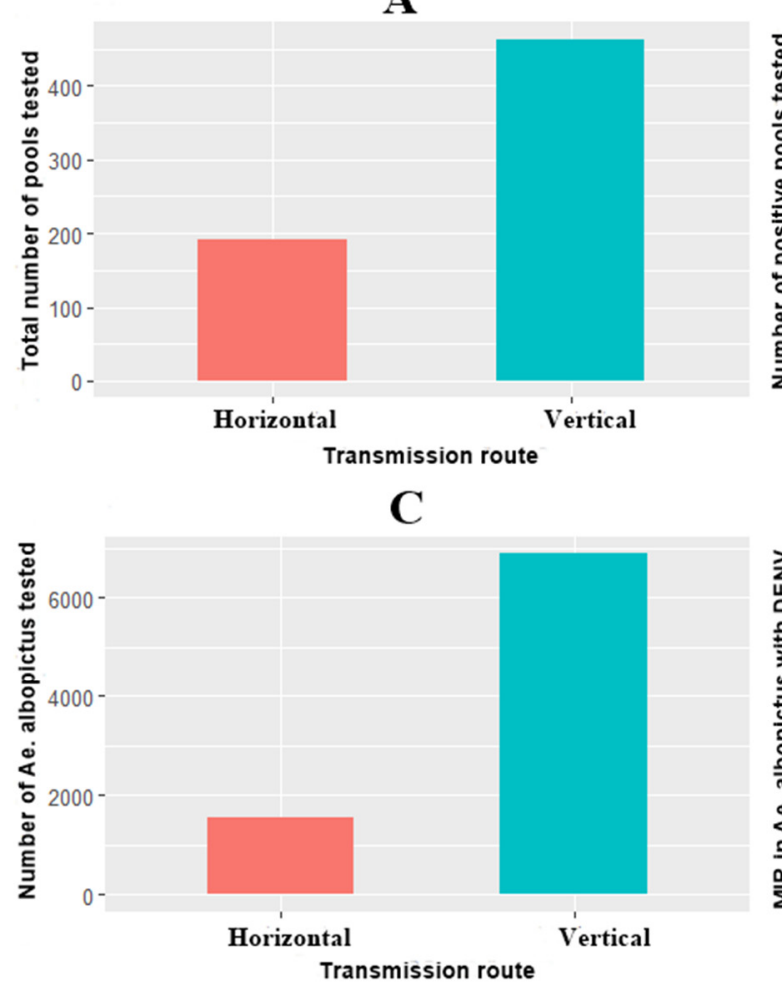

B
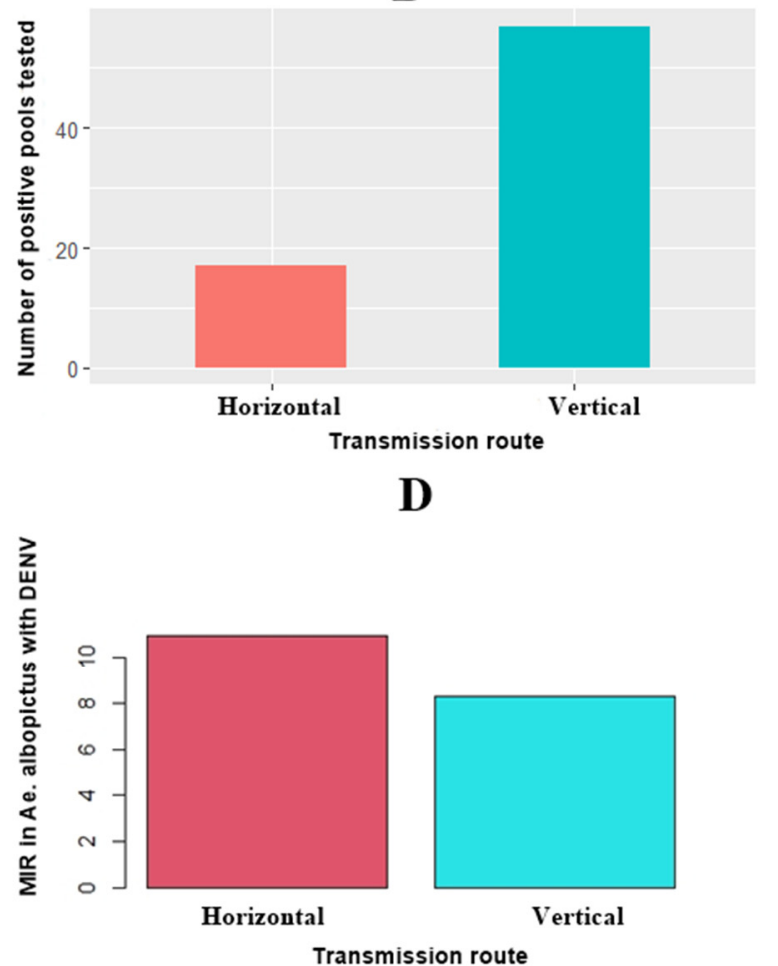

Figure 1. Aedes albopictus infected with DENV. (A) Total number of pools tested, (B) Number of positive pools tested, (C) Number of Ae. albopictus tested, and (D) MIR.

In a deeper analysis, it has been observed that there is a difference in the MIR values in vertical transmission if the DENV is identified from larvae [58,63-65] or adults emerged from a collection of eggs or larvae [55,57,60,61,66-68]. MIR estimated from larvae is 14.04 $(41 / 2921)$ and $4.04(16 / 3962)$ in adults per 1000 mosquitoes tested. The estimated MIR in Ae. albopictus larvae infected with DENV is in the range of 1.77 to 28.20 [58,63-65]. Pessanha and collaborators [65] estimated the MIR of 138 in Ae. aegypti larvae infected with DENV. The identification of DENV from the larvae of both mosquitoes is apparently very successful.

In many geographic areas of the Americas, Ae. albopictus occupies the same ecological niches as Ae. aegypti. It is difficult to incriminate the tiger mosquito as the cause of autochthonous arbovirus outbreaks [11,60,61]. In horizontal transmission, Ae. aegypti is considered the main vector of dengue, Zika, and chikungunya viruses in American countries [11-14,53], while the Asian mosquito is considered a secondary vector in the transmission of these viruses. However, evidence suggests that Ae. albopictus is effective in transmitting the dengue and Zika both horizontal and vertical transmission $[11,14,47,52-$ 55,57-61,63-68]. Notably, 11 out of 14 publications refer to transovarial transmission of the dengue virus $[55,57,58,60,61,63-68]$. This has several aspects; the dengue virus can remain and persist silently during interepidemic periods [56,68]. The dispersal of eggs and larvae of Ae. albopictus infected with dengue and Zika viruses can cause the emergence and re-emergence of arboviruses and modify the local epidemiological pattern $[47,58,59,62-65,68]$. Transovarial transmission ensures the presence of arboviruses in Ae. albopictus regardless of blood feeding on viremic hosts. The occurrence of male mosquitoes infected by transovarial transmission suggests an equal probability of infection of the females of the same batch. Females of Ae. albopictus would not have to go through the extrinsic incubation period to transmit the virus to humans, which would enhance the dynamics of dengue transmission [60]. In addition, serotypes and genotypes not associated with autochthonous outbreaks have been detected during transovarial transmission. In Brazil, genotype III of DENV-3 was detected in larvae of Ae. albopictus collected in 1999 [63]. 
Nevertheless, DENV-3 (genotype III) was first isolated as an autochthonous case from a 40-year-old woman residing in Sao Paulo, Brazil [78], which suggests that this serotype was present in Brazil one year before its detection. Similarly, DENV-3 was detected in males of Ae. albopictus in years when no human autochthonous cases of this serotype were recorded in São Paulo, Brazil [68].

\section{Concluding Remarks and Future Prospects}

Despite the importance of Ae. albopictus as a vector and reservoir of dengue virus, few studies have evaluated the vectorial capacity in the Americas. Studies should focus on gonotrophic cycle length, dispersion range, daily survival probability, parity index and the proportion of bites made by females on humans. Likewise, in Asian mosquito populations, the susceptibility status and genes associated with resistance to insecticides used by local health services should be monitored. Finally, it is important to highlight that Ae. albopictus is an invasive mosquito with wide phenotypic plasticity to adapt to broad and new areas, it is highly efficient to transmit the DENV horizontally and vertically, it can participate in the inter-endemic transmission of the dengue disease, and it can spread zoonotic arboviruses across urban and peri-urban settings as well as natural settings. According to the MIR values of DENV, which were similar in horizontal $(\mathrm{MIR}=10.95)$ and vertical transmission $(\mathrm{MIR}=8.28)$, Ae. albopictus could participate in the natural cycle of transmission of DENV horizontally as the main vector Ae. aegypti and could also be useful as a sentinel species to monitor DENV in inter-epidemic periods.

Author Contributions: C.M.B.-B. wrote the first draft of the manuscript with considerable assistance from J.E.G.-R., N.C.-T. and J.-C.N. All authors contributed to manuscript revision. All authors have read and agreed to the published version of the manuscript.

Funding: This study was funded by the Universidad Internacional SEK, Quito, Ecuador. Grant DII-UISEK P011617_2.

Institutional Review Board Statement: Not applicable.

Informed Consent Statement: Not applicable.

Acknowledgments: To Silvia Valencia Navarrete (Director of Language Institute UISEK), and Karen Garzon Sherdek (Director of International Office-UISEK) for revision of English and redaction suggestions.

Conflicts of Interest: The authors declare no conflict of interest.

\section{References}

1. Gratz, N.G. Critical review of the vector status of Aedes albopictus. Med. Vet. Entomol. 2004, 18, 215-227. [CrossRef]

2. Watson, M.S. Aedes (Stegomyia) albopictus (Skuse): A literature review. Misc. Publ. 1967, 22, 1-38.

3. Kraemer, M.U.G.; Sinka, M.E.; Duda, K.A.; Mylne, A.; Shearer, F.M.; Brady, O.J.; Messina, J.P.; Barker, C.M.; Moore, C.G.; Carvalho, R.G. The global compendium of Aedes aegypti and Ae. albopictus occurrence. Sci. Data 2015, 2, 1-8. [CrossRef] [PubMed]

4. La Ruche, G.; Souarès, Y.; Armengaud, A.; Peloux-Petiot, F.; Delaunay, P.; Desprès, P.; Lenglet, A.; Jourdain, F.; Leparc-Goffart, I.; Charlet, F. First two autochthonous dengue virus infections in metropolitan France, September 2010. Eurosurveillance 2010, 15, 19676. [CrossRef] [PubMed]

5. Monge, S.; García-Ortúzar, V.; Hernández, B.L.; Pérez, M.Á.L.; Delacour-Estrella, S.; Sánchez-Seco, M.P.; Martinez, B.F.; San Miguel, L.G.; García-Fulgueiras, A.; Moros, M.J.S. Characterization of the first autochthonous dengue outbreak in Spain (AugustSeptember 2018). Acta Trop. 2020, 205, 105402. [CrossRef]

6. Lazzarini, L.; Barzon, L.; Foglia, F.; Manfrin, V.; Pacenti, M.; Pavan, G.; Rassu, M.; Capelli, G.; Montarsi, F.; Martini, S. First autochthonous dengue outbreak in Italy, August 2020. Eurosurveillance 2020, 25, 2001606. [CrossRef]

7. Bonilauri, P.; Bellini, R.; Calzolari, M.; Angelini, R.; Venturi, L.; Fallacara, F.; Cordioli, P.; Angelini, P.; Venturelli, C.; Merialdi, G. Chikungunya virus in Aedes albopictus, Italy. Emerg. Infect. Dis. 2008, 14, 852. [CrossRef] [PubMed]

8. Giron, S.; Franke, F.; Decoppet, A.; Cadiou, B.; Travaglini, T.; Thirion, L.; Durand, G.; Jeannin, C.; L'ambert, G.; Grard, G. Vector-borne transmission of Zika virus in Europe, southern France, August 2019. Eurosurveillance 2019, 24, 1900655. [CrossRef]

9. Salles, T.S.; da Encarnação Sá-Guimarães, T.; de Alvarenga, E.S.L.; Guimarães-Ribeiro, V.; de Meneses, M.D.F.; de Castro-Salles, P.F.; Dos Santos, C.R.; do Amaral Melo, A.C.; Soares, M.R.; Ferreira, D.F. History, epidemiology and diagnostics of dengue in the American and Brazilian contexts: A review. Parasit. Vectors 2018, 11, 1-12. [CrossRef] 
10. Vasconcelos, P.F.C.; Powers, A.M.; Hills, S. The emergence of Chikungunya and Zika viruses in the Americas. In Chikungunya and Zika Viruses; Elsevier: Amsterdam, The Netherlands, 2018; pp. 215-235. [CrossRef]

11. Méndez, F.; Barreto, M.; Arias, J.F.; Rengifo, G.; Munoz, J.; Burbano, M.E.; Parra, B. Human and mosquito infections by dengue viruses during and after epidemics in a dengue-endemic region of Colombia. Am. J. Trop. Med. Hyg. 2006, 74, 678-683. [CrossRef]

12. Díaz-González, E.E.; Kautz, T.F.; Dorantes-Delgado, A.; Malo-García, I.R.; Laguna-Aguilar, M.; Langsjoen, R.M.; Chen, R.; Auguste, D.I.; Sánchez-Casas, R.M.; Danis-Lozano, R. First report of Aedes aegypti transmission of chikungunya virus in the Americas. Am. J. Trop. Med. Hyg. 2015, 93, 1325-1329. [CrossRef]

13. Cigarroa-Toledo, N.; Blitvich, B.J.; Cetina-Trejo, R.C.; Talavera-Aguilar, L.G.; Baak-Baak, C.M.; Torres-Chablé, O.M.; Hamid, M.N.; Friedberg, I.; González-Martinez, P.; Alonzo-Salomon, G.; et al. Chikungunya virus in febrile humans and Aedes aegypti mosquitoes, Yucatan, Mexico. Emerg. Infect. Dis. 2016, 22, 1804. [CrossRef] [PubMed]

14. Huerta, H.; González-Roldán, J.F.; Sánchez-Tejeda, G.; Correa-Morales, F.; Romero-Contreras, F.E.; Cárdenas-Flores, R.; RangelMartínez, M.L.; Mata-Rivera, J.M.; Siller-Martínez, J.D.J.; Vazquez-Prokopec, G.M. Detection of Zika virus in Aedes mosquitoes from Mexico. Trans. R. Soc. Trop. Med. Hyg. 2017, 111, 328-331. [CrossRef] [PubMed]

15. Reiter, P. Aedes albopictus and the world trade in used tires, 1988-1995: The shape of things to come? J. Am. Mosq. Control Assoc. 1998, 14, 83-94.

16. Forattini, O.P. Identificação de Aedes (Stegomyia) albopictus (skuse) no Brasil. Rev. Saude Publica 1986, 20, 244-245. [CrossRef] [PubMed]

17. Ibáñez-Bernal, S.; Martínez-Campos, C. Aedes albopictus in Mexico. J. Am. Mosq. Control Assoc. 1994, 10, $231-232$.

18. Broche, R.G.; Borja, E.M. Aedes albopictus in Cuba. J. Am. Mosq. Control Assoc. 1999, 15, 569-570.

19. Peña, C.J. First report of Aedes (Stegomyia) albopictus (Skuse) from the Dominican Republic. Vector Ecol. Newsl. 1993, $24,68$.

20. Ogata, K. Discovery of Aedes albopictus in Guatemala. J. Am. Mosq. Control Assoc. 1996, 12, 503-506.

21. Wheeler, A.S.; Petrie, W.D.; Malone, D.; Allen, F. Introduction, control, and spread of Aedes albopictus on Grand Cayman Island, 1997-2001. J. Am. Mosq. Control Assoc. 2009, 25, 251-259. [CrossRef] [PubMed]

22. Vélez, I.D.; Quiñones, M.L.; Suarez, M.; Olano, V.; Murcia, L.M.; Correa, E.; Arévalo, C.; Pérez, L.; Brochero, H.; Morales, A. Presencia de Aedes albopictus en Leticia, Amazonas, Colombia. Biomédica 1998, 18, 192-198. [CrossRef]

23. Rossi, G.C.; Pascual, N.T.; Krsticevic, F.J. First record of Aedes albopictus (Skuse) from Argentina. J. Am. Mosq. Control Assoc. News $1999,15,422$.

24. Kaplan, L.; Kendell, D.; Robertson, D.; Livdahl, T.; Khatchikian, C. Aedes aegypti and Aedes albopictus in Bermuda: Extinction, invasion, invasion and extinction. Biol. Invasions 2010, 12, 3277-3288. [CrossRef]

25. Futami, K.; Valderrama, A.; Baldi, M.; Minakawa, N.; Marin Rodriguez, R.; Chaves, L.F. New and common haplotypes shape genetic diversity in Asian tiger mosquito populations from Costa Rica and Panamá. J. Econ. Entomol. 2015, 108, 761-768. [CrossRef]

26. Thielman, A.C.; Hunter, F.F. A Photographic Key to Adult Female Mosquito Species of Canada (Diptera: Culicidae). Can. J. Arthropod Identif. 2007, 4, 1-117. [CrossRef]

27. Chadee, D.D.; Fat, F.H.; Persad, R.C. First record of Aedes albopictus from Trinidad, West Indies. J. Am. Mosq. Control Assoc. 2003, $19,438-439$.

28. Rossi, G.C.; Martínez, M. Mosquitos (Diptera: Culicidae) del Uruguay. Entomol Vect 2003, 10, 469.

29. Lugo, E.D.C.; Moreno, G.; Zachariah, M.A.; López, M.M.; López, J.D.; Delgado, M.A.; Valle, S.I.; Espinoza, P.M.; Salgado, M.J.; Pérez, R. Identification of Aedes albopictus in urban Nicaragua. J. Am. Mosq. Control Assoc. 2005, 21, 325-327. [CrossRef]

30. Marín, R.; del Carmen Marquetti, M.; Álvarez, Y.; Gutiérrez, J.M.; González, R. Especies de mosquitos (Diptera: Culicidae) y sus sitios de cría en la Región Huetar Atlántica, Costa Rica. Rev. Biomédica 2009, 20, 15-23.

31. Navarrro, J.-C.; Zorrilla, A.; Moncada, N. Primer registro de Aedes albopictus (Skuse) en Venezuela: Importancia como vector de Dengue y acciones a desarrollar. Boletín Malariol. y Salud Ambient. 2009, 49, 161-166.

32. Ortega-Morales, A.I.; Mis-Avila, P.; Domínguez-Galera, M.; Canul-Amaro, G.; Esparza-Aguilar, J.; Carlos-Azueta, J.; Badillo-Perry, S.; Marin, P.; Polanco, J.; Fernández-Salas, I. First record of Stegomyia albopicta [Aedes albopictus] in Belize. Southwest. Entomol. 2010, 35, 197-198. [CrossRef]

33. Marquetti Fernández, M.D.; Jean, Y.S.; Fuster Callaba, C.A.; Somarriba López, L. The first report of Aedes (Stegomyia) albopictus in Haiti. Mem. Inst. Oswaldo Cruz 2012, 107, 279-281. [CrossRef]

34. Ali, I.; Mundle, M.; Anzinger, J.J.; Sandiford, S.L. Tiger in the sun: A report of Aedes albopictus in Jamaica. Acta Trop. 2019, 199, 105112. [CrossRef]

35. Ponce, P.; Morales, D.; Argoti, A.; Cevallos, V.E. First Report of Aedes (Stegomyia) albopictus (Skuse) (Diptera: Culicidae), the Asian Tiger Mosquito, in Ecuador. J. Med. Entomol. 2018, 55, 248-249. [CrossRef] [PubMed]

36. Savage, H.M.; Niebylski, M.L.; Smith, G.C.; Mitchell, C.J.; Craig Jr, G.B. Host-feeding patterns of Aedes albopictus (Diptera: Culicidae) at a temperate North American site. J. Med. Entomol. 1993, 30, 27-34. [CrossRef]

37. Stenn, T.; Peck, K.J.; Rocha Pereira, G.; Burkett-Cadena, N.D. Vertebrate hosts of Aedes aegypti, Aedes albopictus, and Culex quinquefasciatus (Diptera: Culicidae) as potential vectors of Zika virus in Florida. J. Med. Entomol. 2019, 56, 10-17. [CrossRef] [PubMed]

38. Niebylski, M.L.; Savage, H.M.; Nasci, R.S.; Craig Jr, G.B. Blood hosts of Aedes albopictus in the United States. J. Am. Mosq. Control Assoc. 1994, 10, 447-450. 
39. Gomes, A.C.; Silva, N.N.; Marques, G.R.; Brito, M. Host-feeding patterns of potential human disease vectors in the Paraíba Valley region, State of Säo Paulo, Brazil. J. Vector Ecol. J. Soc. Vector Ecol. 2003, 28, 74-78.

40. Gingrich, J.B.; Williams, G.M. Host-feeding patterns of suspected West Nile virus mosquito vectors in Delaware, 2001-2002. J. Am. Mosq. Control Assoc. 2005, 21, 194-200. [CrossRef]

41. Richards, S.L.; Ponnusamy, L.; Unnasch, T.R.; Hassan, H.K.; Apperson, C.S. Host-feeding patterns of Aedes albopictus (Diptera: Culicidae) in relation to availability of human and domestic animals in suburban landscapes of central North Carolina. J. Med. Entomol. 2006, 43, 543-551. [CrossRef] [PubMed]

42. Tuten, H.C.; Bridges, W.C.; Paul, K.S.; Adler, P.H. Blood-feeding ecology of mosquitoes in zoos. Med. Vet. Entomol. 2012, 26, 407-416. [CrossRef] [PubMed]

43. Faraji, A.; Egizi, A.; Fonseca, D.M.; Unlu, I.; Crepeau, T.; Healy, S.P.; Gaugler, R. Comparative host feeding patterns of the Asian tiger mosquito, Aedes albopictus, in urban and suburban Northeastern USA and implications for disease transmission. PLoS Negl. Trop. Dis. 2014, 8, e3037. [CrossRef] [PubMed]

44. Goodman, H.; Egizi, A.; Fonseca, D.M.; Leisnham, P.T.; LaDeau, S.L. Primary blood-hosts of mosquitoes are influenced by social and ecological conditions in a complex urban landscape. Parasit. Vectors 2018, 11, 218. [CrossRef] [PubMed]

45. Pereira dos Santos, T.; Roiz, D.; Santos de Abreu, F.V.; Luz, S.L.B.; Santalucia, M.; Jiolle, D.; Santos Neves, M.S.A.; Simard, F.; Lourenço-de-Oliveira, R.; Paupy, C. Potential of Aedes albopictus as a bridge vector for enzootic pathogens at the urban-forest interface in Brazil. Emerg. Microbes Infect. 2018, 7, 1-8. [CrossRef]

46. Dennett, J.A.; Bala, A.; Wuithiranyagool, T.; Randle, Y.; Sargent, C.B.; Guzman, H.; Siirin, M.; Hassan, H.K.; Reyna-Nava, M.; Unnasch, T.R. Associations between two mosquito populations and West Nile virus in Harris County, Texas, 2003-2006. J. Am. Mosq. Control Assoc. 2007, 23, 264. [CrossRef]

47. Alencar, J.; Ferreira de Mello, C.; Brisola Marcondes, C.; Érico Guimarães, A.; Toma, H.K.; Queiroz Bastos, A.; Olsson Freitas Silva, S.; Lisboa Machado, S. Natural Infection and Vertical Transmission of Zika Virus in Sylvatic Mosquitoes Aedes albopictus and Haemagogus leucocelaenus from Rio de Janeiro, Brazil. Trop. Med. Infect. Dis. 2021, 6, 99. [CrossRef] [PubMed]

48. Mitchell, C.J.; Niebylski, M.L.; Smith, G.C.; Karabatsos, N.; Martin, D.; Mutebi, J.P.; Craig, G.B.; Mahler, M.J. Isolation of eastern equine encephalitis virus from Aedes albopictus in Florida. Science 1992, 257, 526-527. [CrossRef]

49. Mitchell, C.J.; Haramis, L.D.; Karabatsos, N.; Smith, G.C.; Starwalt, V.J. Isolation of La Crosse, Cache Valley, and Potosi viruses from Aedes mosquitoes (Diptera: Culicidae) collected at used-tire sites in Illinois during 1994-1995. J. Med. Entomol. 1998, 35, 573-577. [CrossRef]

50. Holick, J.; Kyle, A.; Ferraro, W.; Delaney, R.R.; Iwaseczko, M. Discovery of Aedes albopictus infected with west nile virus in southeastern Pennsylvania. J. Am. Mosq. Control Assoc. 2002, 18, 131.

51. Armstrong, P.M.; Anderson, J.F.; Farajollahi, A.; Healy, S.P.; Unlu, I.; Crepeau, T.N.; Gaugler, R.; Fonseca, D.M.; Andreadis, T.G. Isolations of Cache Valley virus from Aedes albopictus (Diptera: Culicidae) in New Jersey and evaluation of its role as a regional arbovirus vector. J. Med. Entomol. 2013, 50, 1310-1314. [CrossRef]

52. Gómez-Palacio, A.; Suaza-Vasco, J.; Castaño, S.; Triana, O.; Uribe, S. Infección de Aedes albopictus (Skuse, 1894) con el genotipo asiático-americano del virus del dengue serotipo 2 en Medellín y su posible papel como vector del dengue en Colombia. Biomédica 2017, 37, 135-142. [CrossRef]

53. Correa-Morales, F.; González-Acosta, C.; Mejía-Zúñiga, D.; Huerta, H.; Pérez-Rentería, C.; Vazquez-Pichardo, M.; Ortega-Morales, A.I.; Hernández-Triana, L.M.; Salazar-Bueyes, V.M.; Moreno-García, M. Surveillance for Zika in Mexico: Naturally infected mosquitoes in urban and semi-urban areas. Pathog. Glob. Health 2019, 113, 309-314. [CrossRef] [PubMed]

54. Ricas Rezende, H.; Malta Romano, C.; Morales Claro, I.; Santos Caleiro, G.; Cerdeira Sabino, E.; Felix, A.C.; Bissoli, J.; Hill, S.; Rodrigues Faria, N.; Cardoso da Silva, T.C. First report of Aedes albopictus infected by Dengue and Zika virus in a rural outbreak in Brazil. PLoS ONE 2020, 15, e0229847. [CrossRef] [PubMed]

55. Calderón-Arguedas, O.; Troyo, A.; Moreira-Soto, R.D.; Marín, R.; Taylor, L. Dengue viruses in Aedes albopictus Skuse from a pineapple plantation in Costa Rica. J. Vector Ecol. 2015, 40, 184-186. [CrossRef]

56. Ferreira-de-Lima, V.H.; Lima-Camara, T.N. Natural vertical transmission of dengue virus in Aedes aegypti and Aedes albopictus: A systematic review. Parasit. Vectors 2018, 11, 1-8. [CrossRef]

57. Maia, L.M.S.; Bezerra, M.C.F.; Costa, M.C.S.; Souza, E.M.; Oliveira, M.E.B.; Ribeiro, A.L.M.; Miyazaki, R.D.; Slhessarenko, R.D. Natural vertical infection by dengue virus serotype 4, Zika virus and Mayaro virus in Aedes (Stegomyia) aegypti and Aedes (Stegomyia) albopictus. Med. Vet. Entomol. 2019, 33, 437-442. [CrossRef]

58. Serufo, J.C.; de Oca, H.M.; Tavares, V.A.; Souza, A.M.; Rosa, R.V.; Jamal, M.C.; Lemos, J.R.; Oliveira, M.A.; Nogueira, R.M.; Schatzmayr, H.G. Isolation of dengue virus type 1 from larvae of Aedes albopictus in Campos Altos city, State of Minas Gerais, Brazil. Mem. Inst. Oswaldo Cruz 1993, 88, 503-504. [CrossRef] [PubMed]

59. Maniero, V.C.; Rangel, P.S.C.; Coelho, L.M.C.; Silva, C.S.B.; Aguiar, R.S.; Lamas, C.C.; Cardozo, S.V. Identification of Zika virus in immature phases of Aedes aegypti and Aedes albopictus: A surveillance strategy for outbreak anticipation. Braz. J. Med. Biol. Res. 2019, 52, e8339. [CrossRef]

60. Rúa-Uribe, G.L.; Giraldo-Jaramillo, T.M.; Triana-Chávez, O.; Rojo, R.; Henao, E.; Pérez-Pérez, J. Transmisión vertical de virus dengue en Aedes spp.(Diptera: Culicidae) en Medellín, Colombia. Rev. Colomb. Entomol. 2020, 46, e6973. [CrossRef] 
61. Ibañez-Bernal, S.; Briseno, B.; Mutebi, J.P.; Argot, E.; Rodriguez, G.; Martinez-Campos, C.; Paz, R.; Roman, P.D.L.F.; Tapia-Conyer, R.; Flisser, A. First record in America of Aedes albopictus naturally infected with dengue virus during the 1995 outbreak at Reynosa, Mexico. Med. Vet. Entomol. 1997, 11, 305-309. [CrossRef]

62. Gerhardt, R.R.; Gottfried, K.L.; Apperson, C.S.; Davis, B.S.; Erwin, P.C.; Smith, A.B.; Panella, N.A.; Powell, E.E.; Nasci, R.S. First isolation of La Crosse virus from naturally infected Aedes albopictus. Emerg. Infect. Dis. 2001, 7, 807. [CrossRef] [PubMed]

63. De Figueiredo, M.L.; de C Gomes, A.; Amarilla, A.A.; de S Leandro, A.; de S Orrico, A.; De Araujo, R.F.; do SM Castro, J.; Durigon, E.L.; Aquino, V.H.; Figueiredo, L.T.M. Mosquitoes infected with dengue viruses in Brazil. Virol. J. 2010, 7, 1-5. [CrossRef] [PubMed]

64. Cecílio, A.B.; Campanelli, E.S.; Souza, K.P.R.; Figueiredo, L.B.; Resende, M. Natural vertical transmission by Stegomyia albopicta as dengue vector in Brazil. Braz. J. Biol. 2009, 69, 123-127. [CrossRef] [PubMed]

65. Pessanha, J.E.M.; Caiaffa, W.T.; Cecilio, A.B.; Iani, F.C.D.M.; Araujo, S.C.; Nascimento, J.C.; Kroon, E.G.; Proietti, F.A.; Arias, J.R. Cocirculation of two dengue virus serotypes in individual and pooled samples of Aedes aegypti and Aedes albopictus larvae. Rev. Soc. Bras. Med. Trop. 2011, 44, 103-105. [CrossRef]

66. Martins, V.E.P.; Alencar, C.H.; Kamimura, M.T.; de Carvalho Araujo, F.M.; De Simone, S.G.; Dutra, R.F.; Guedes, M.I.F. Occurrence of natural vertical transmission of dengue-2 and dengue-3 viruses in Aedes aegypti and Aedes albopictus in Fortaleza, Ceará, Brazil. PLoS ONE 2012, 7, e41386. [CrossRef]

67. Sanchez-Rodríguez, O.S.; Sanchez-Casas, R.M.; Laguna-Aguilar, M.; Alvarado-Moreno, M.S.; Zarate-Nahon, E.A.; RamirezJimenez, R.; de la Garza, C.E.M.; Torres-Zapata, R.; Dominguez-Galera, M.; Mis-Avila, P. Natural transmission of dengue virus by Aedes albopictus at Monterrey, Northeastern Mexico. Southwest. Entomol. 2014, 39, 459-468. [CrossRef]

68. Ferreira-de-Lima, V.H.; dos Santos Andrade, P.; Thomazelli, L.M.; Marrelli, M.T.; Urbinatti, P.R.; de Sá Almeida, R.M.M.; LimaCamara, T.N. Silent circulation of dengue virus in Aedes albopictus (Diptera: Culicidae) resulting from natural vertical transmission. Sci. Rep. 2020, 10, 1-8.

69. Eritja, R.; Palmer, J.R.B.; Roiz, D.; Sanpera-Calbet, I.; Bartumeus, F. Direct evidence of adult Aedes albopictus dispersal by car. Sci. Rep. 2017, 7, 1-15. [CrossRef]

70. Amraoui, F.; Pain, A.; Piorkowski, G.; Vazeille, M.; Couto-Lima, D.; de Lamballerie, X.; Lourenço-de-Oliveira, R.; Failloux, A.-B. Experimental adaptation of the yellow fever virus to the mosquito Aedes albopictus and potential risk of urban epidemics in Brazil, South America. Sci. Rep. 2018, 8, 1-8. [CrossRef]

71. Chouin-Carneiro, T.; Vega-Rua, A.; Vazeille, M.; Yebakima, A.; Girod, R.; Goindin, D.; Dupont-Rouzeyrol, M.; Lourenco-deOliveira, R.; Failloux, A.-B. Differential susceptibilities of Aedes aegypti and Aedes albopictus from the Americas to Zika virus. PLoS Negl. Trop. Dis. 2016, 10, e0004543. [CrossRef]

72. Moore, C.G.; Mitchell, C.J. Aedes albopictus in the United States: Ten-year presence and public health implications. Emerg. Infect. Dis. 1997, 3, 329. [CrossRef] [PubMed]

73. Vega-Rúa, A.; Zouache, K.; Girod, R.; Failloux, A.-B.; Lourenço-de-Oliveira, R. High level of vector competence of Aedes aegypti and Aedes albopictus from ten American countries as a crucial factor in the spread of Chikungunya virus. J. Virol. 2014, 88, 6294-6306. [CrossRef] [PubMed]

74. Vazeille, M.; Moutailler, S.; Coudrier, D.; Rousseaux, C.; Khun, H.; Huerre, M.; Thiria, J.; Dehecq, J.-S.; Fontenille, D.; Schuffenecker, I. Two Chikungunya isolates from the outbreak of La Reunion (Indian Ocean) exhibit different patterns of infection in the mosquito, Aedes albopictus. PLoS ONE 2007, 2, e1168. [CrossRef] [PubMed]

75. Baak-Baak, C.M.; Cigarroa-Toledo, N.; Cruz-Escalona, G.A.; Machain-Williams, C.; Rubi-Castellanos, R.; Torres-Chable, O.M.; Torres-Zapata, R.; Garcia-Rejon, J.E. Human blood as the only source of aedes aegypti in churches from merida, yucatan, mexico. J. Vector Borne Dis. 2018, 55, 58. [CrossRef] [PubMed]

76. Garcia-Rejon, J.; Loroño-Pino, M.A.; Farfan-Ale, J.A.; Flores-Flores, L.; Rosado-Paredes, E.D.P.; Rivero-Cardenas, N.; NajeraVazquez, R.; Gomez-Carro, S.; Lira-Zumbardo, V.; Gonzalez-Martinez, P.; et al. Dengue virus-infected Aedes aegypti in the home environment. Am. J. Trop. Med. Hyg. 2008, 79, 940-950. [CrossRef] [PubMed]

77. Scott, T.W.; Morrison, A.C.; Lorenz, L.H.; Clark, G.G.; Strickman, D.; Kittayapong, P.; Zhou, H.; Edman, J.D. Longitudinal studies of Aedes aegypti (Diptera: Culicidae) in Thailand and Puerto Rico: Population dynamics. J. Med. Entomol. 2000, 37, 77-88. [CrossRef]

78. Nogueira, R.M.R.; Miagostovich, M.P.; de Filippis, A.M.B.; Pereira, M.A.S.; Schatzmayr, H.G. Dengue virus type 3 in Rio de Janeiro, Brazil. Mem. Inst. Oswaldo Cruz 2001, 96, 925-926. [CrossRef] [PubMed] 